\title{
EFL Teachers' Practices and the Learners Perception Towards the Use of Amharic in English Classes at Secondary Schools of Wolaita Zone, Ethiopia
}

\author{
Faskal Faranso Faltamo \\ Faculty of Social Science and Humanities, Department of English Language and Literature, Wolaita Sodo University, Sodo, Ethiopia

\section{Email address:} \\ pascallove39@gmail.com

\section{To cite this article:} \\ Faskal Faranso Faltamo. EFL Teachers' Practices and the Learners Perception towards the Use of Amharic in English Classes at Secondary \\ Schools of Wolaita Zone, Ethiopia. International Journal of Secondary Education. Vol. 4, No. 3, 2019, pp. 48-53. \\ doi: 10.11648/j.ijecs.20190403.11
}

Received: June 8, 2019; Accepted: July 5, 2019; Published: August 10, 2019

\begin{abstract}
The use of learners' first language in EFL classrooms has long received attention in the literature. Despite, the focus has often been on its implementations as well as advantages and disadvantages. Unfortunately, less research has been conducted regarding students' perceptions on its use. Hence, the purpose of the study was exploring EFL teachers' practices and learners' perceptions about use of Amharic in English language classrooms at four selected secondary schools at Wolaita zone, Ethiopia. To achieve the intended objectives, the researcher employed descriptive research design with mixed methods of data collections. Totally, 178 students and three English language teachers were direct participants of the study as sources of data. The results obtained through questionnaire, interview and classroom observation were analyzed by using mixed methods of data analysis. It was found out that Most of the EFL teachers used Amharic for different purposes while teaching English. Based on findings of the study, it was concluded that Amharic is commonly used by EFL teachers in classes because most of their students felt more comfortable while using Amharic in actual classroom teaching-learning process.
\end{abstract}

Keywords: EFL, Practices, Perception, Amharic, Instructions, Secondary Schools

\section{Background of the Study}

Throughout the history of language teaching, methods of classroom instruction has been one of the most controversial topics of debate among different scholars. Though there have been numerous studies carried out to find the ways of more effective language instruction, there still no single and agreed up on consensus among the scholars. However, Mohammed Hamid Al Ta'ani, 2019 stated that the center for debate among the scholars in this case have relied on monolingual approach that rejects first language use in EFL classes and use of learners' first language or mother tongue [1]. The supporters of the later approach consider it as early teaching practice, and it was considered impossible to teach a second language without using the first language of the learners. According to such scholars, the use of learners' first language or mother tongue is simply favored for it is easy to understand and saves the communicative Breakdowns during EFL classes. Again, it is also favored for its support to explain the concepts and lexical parallels and equivalents in the first language ([2-5]). For this reason, the issue of first language use in EFL learning context has got considerable attention from different scholars worldwide. According to Seyed Ali Ostovar-Namaghi, Shabnam Norouzi, 2015 far from being an obstacle for some scholars, learners' first language is a precious resource.

In the same vein, it has also caught attention of different scholars from countries like Ethiopia where English is taught as foreign language. Turan Pakera, and Özlem Karaagaç 2015 has favored the use of mother tongue contribution to language learning process in various occasions in the learning-teaching process but the excessive use of it may result in too much dependence on it, which is less desired outcome [6]. Similarly, some local studies conducted in Ethiopia indicated its importance in EFL classroom instructions. For instance, Kifle Bidika, Temesgen Mereba, and Yemanebirhan Kelemework, 2017; Abyi and Mohammed, 2011; and Abiy Yigzaw, 2012 were few works 
to mention whose work supported the use of Amharic in EFL classes ([7-9]). These scholars favored the use of Amharic if not used excessively to support the students learning.

\section{Statement of the Problem}

Language Teaching is a challenging profession in today's changing world. In first place, the patterns of teachers' classroom language can provide useful information concerning their students' attitude towards its use. In Ethiopia, almost all EFL teachers speak one of the countries' languages in the classroom. According to Kifle Bidika, Temesgen Mereba, and Yemanebirhan Kelemework, 2017, the teachers unconditionally use Amharic in EFL classrooms [7]. Besides, the study conducted by Abyi and Mohammed, 2011 in Bahir Dar elementary schools indicated positive correlation between EFL teachers' use of Amharic (L1) in classroom and the learners' attitude towards its use [8]. Again, Abiy Yigzaw, 2012 focused on the use of Amharic during English pre-writing lesson at Belay Zeleke Preparatory School and still his study favored the use of it for its relevance to enhance students writing ability [9]. However, what makes current study different from previous ones is that Amharic is the second language for students in Wolaita zone. That is, Wolaita language is native (L1) to the participants of current study and thus their perceptions towards Amharic (L2) use in EFL classes cannot easily be identified. Hence, the discrepancy between teachers' practices and the students' unidentified perceptions towards the use Amharic in EFL classes at secondary schools in Wolaita zone have motivated the researcher to undertake this study.

\section{Objectives of the Study}

\subsection{General Objective}

Aim of current study was Investigating EFL Teachers' practices and the learners' perception towards the use of Amharic during English language Classrooms at some selected secondary schools in Wolaita zone, Ethiopia.

\subsection{Specific Objectives}

Specific objectives of this study were:

To introduce the situations of EFL Teachers' use of Amharic in EFL classes.

To discuss the EFL teachers' implementations of classroom language use.

To analyze learners' perception on their teachers' use of Amharic in EFL classes.

\section{Significances of the Study}

Teaching English language in Ethiopian secondary schools has focused on developing students' language skills for successful learning. This becomes effective when EFL teachers use target language appropriately in classroom though some of them use L1 to support it. For this reason, the researcher strongly believed current study fills this gap by creating awareness among teachers towards side effects of dominants uses of Mother tongues in EFL classes. Besides, it improves students' motivations to learn English as their teachers effectively use it in classes. Moreover, it promotes quality education as the students effectively learn their lesson through target language. Finally, it helped to recommend teachers to reduce over use of Amharic in English classes.

\section{Methodology of the Study}

\subsection{Research Design}

The purpose of this study was to investigate teachers' practices and students' perceptions towards the use of Amharic in English classes with particular reference four secondary schools in Wolaita zone, Ethiopia. Taking the nature of the study into consideration, the researcher used descriptive research for it allowed descriptions of the nature of problems under study. Besides, it helped the researcher to use qualitative and quantitative research methods of data collections.

\subsection{Population of the Study}

Both English language teachers and students in target schools were direct participants of the study. In this school, the total numbers of English teachers were five. Totally, three out of five EFL teachers were randomly selected as a sample. Besides, the total numbers of students in the schools were 591. Among total populations, 178 students containing 112 male and 66 female students were selected by using simple random sampling technique. Hence, total numbers of teachers and students who participated in this study were 181 .

\subsection{Instruments of Data Collection}

One major step in the researcher's engagement in this study was collecting necessary data to find solutions for the problems. This was done through data gathering. The data were gathered through questionnaire, interview and classroom observations. Specifically, total of 178 questionnaires containing open-ended and close-ended questions were prepared and distributed to the students only. It was prepared and administered in English language. Besides, three teachers and six students were participated to respond semi-structured interview questions. Moreover, total of eight non-participant classroom observations were conducted at four schools. The researcher prepared check list and observed actual classroom interactions.

\subsection{Methods of Data Analysis and Interpretation}

The sources of data for current study were secondary school teachers and students in Wolaita zone. The data from the participants were collected through questionnaire, 
interview, and classroom observations. That is, quantitative data were gathered through questionnaire, but interview and observations data were qualitative in nature. So, quantitative data were expressed in numbers and percentage. Besides, qualitative data were transcribed in statement form. Thus, mixed methods of data analysis employed in current study helped the researcher to discuss reliability of the data sources and validity of data. This method of data analysis helped the researcher to triangulate the reliability of each data gathering tool.

\section{Data Analysis and Interpretations}

The objective of current study was Investigating EFL Teachers' practices and the learners' perception towards the use of Amharic during English language Classrooms. To achieve the intended objective, the data were collected from EFL teachers and students of secondary schools through questionnaire interview, and classroom observation. The results obtained via the above tools of data collection were described and presented as follows.

\subsection{Demographic Information of Respondents}

Table 1. The Respondents (Students') Age and Sex Categories.

\begin{tabular}{llll}
\hline Characteristics of respondents & Items & No of respondents & (\%) \\
\hline \multirow{3}{*}{ Sex } & Male (M) & 112 & 63 \\
& Female (F) & 66 & 37 \\
& Total & 178 & 100 \\
Age (in years) & $18-21$ & 139 & 78 \\
& $22-25$ & 28 & 16 \\
& Above 25 years & 11 & 6 \\
& Total & 178 & 100 \\
\hline
\end{tabular}

As presented in table 1 , the numbers of boys $112(63 \%)$ who participated in this study were greater than the numbers of girl respondents $66(37 \%)$. That is, the gender distributions in the study area have shown as it was dominated by male students. Therefore, it could be concluded that most of secondary school attendants who participated in this study were males. Regarding the age distributions, most of the respondents were under twenty years old. Out of total populations, 139 (78\%) respondents were 18-21 years old, whereas $28(16 \%)$ of them were $22-25$ years old. Again, only $11(6 \%)$ of the respondents were above twenty five years old. This data showed that majority of the respondents were adolescents.

Regarding teachers' profiles, there were three male and a female teacher whose educational status is bachelor degree in English language were participated in this study. Most of them have long teaching experiences and matured ones.

Table 2. Responses on Whether EFL Teachers Use Amharic in English Classes or Not.

\begin{tabular}{llll}
\hline & Items & Quantity (No) & Percent (\%) \\
\hline \multirow{2}{*}{ Does your Teacher use Amharic while teaching English lessons? } & Yes & 164 & 92 \\
& No & 14 & 8 \\
\hline
\end{tabular}

Regarding the English language teachers' use of the learners' second language (Amharic), majority of the respondents responded yes to mean their English language teachers used Amharic while teaching English lessons, but few of them opposed it and responded no. That is, 164 (92\%) of the respondents witnessed as their English language teachers use of Amharic in EFL classes and only 14 (8\%) of them responded as their English teachers did not use Amharic in classes.

Besides questionnaire data, the interview and classroom observations were revealed that almost all English language teachers use Amharic while teaching English lesson though the purposes and degree of its usage varies. Moreover, teachers' interview results also proved as they witnessed their use of Amharic in classes. Thus, teaching English in target study area was supported by the use of Amharic.

Table 3. Responses on Frequencies of EFL Teachers Use of Amharic in Classes.

\begin{tabular}{|c|c|c|c|}
\hline & Items & Quantity (No) & Percent (\%) \\
\hline \multirow{3}{*}{ How often your teacher does use Amharic while teaching English lessons? } & Usually & 92 & 52 \\
\hline & Sometimes & 59 & 33 \\
\hline & Rarely & 25 & 14 \\
\hline
\end{tabular}

It is the fact that not all English teachers equally use Amharic while teaching English at Ethiopian secondary schools. For instance, some English teachers use it frequently and dominantly than target language [7]. Supporting this, another finding obtained from Emily Boersma and Yinager Teklesellassie, 2017showed that most of the class time involved the use of Amharic by both teachers and students [10]. In favor of this, current study also revealed that majority of teachers used Amharic to support EFL teaching. Out of total populations, more than half or $92(52 \%)$ respondents agreed that their teachers usually use Amharic in English classes whereas 59 (33\%) of them said their teachers 
sometimes use Amharic in English classes. In contrary, the responses which showed the teachers' less frequent use of Amharic were very few. That is, 25 (14\%) of the respondents reported as their teachers rarely use Amharic in English classes, but only 2 (1\%) of them responded as never.

Moreover, the classroom observation results revealed the overuse of Amharic by some English teachers though there were few teachers who used it slightly based on the contexts if necessary. Teachers' and students' interview results further proved that majority of English teachers were favored Amharic (L2) than target language in the classes. This correlated with the findings from Mahmoudi and Amirkhiz (2011) that EFL teachers use of L1 was quite high. Thus, the frequencies of Amharic use by English teachers in actual classes were high.

Table 4. Responses on the reasons EFL Teachers Use Amharic in Classes.

\begin{tabular}{|c|c|c|c|}
\hline & Items & Quantity (No) & Percent (\%) \\
\hline \multirow{4}{*}{$\begin{array}{l}\text { How and Why your English teacher does use } \\
\text { Amharic in English classes? }\end{array}$} & $\mathrm{He} /$ she lacks English fluency & 72 & 41 \\
\hline & To translate English concepts & 54 & 30 \\
\hline & To favor L1 use in EFL classes & 29 & 16 \\
\hline & To waste time & 5 & 3 \\
\hline
\end{tabular}

Many scholars pointed out that EFL teachers use L1 for many reasons. For instance, Ahmad Shah Qasemi Ainol Haryati Ibrahim and Mohammad Habib Jilani 2016 discovered that teachers used L1 mainly to manage classroom interactions, class activities, reduce waiting time and control turn taking by students. Moreover, the teachers switched to L1 to avoid uncertainty, save time, keep authority, and manage classroom in good manner.

Regarding EFL teachers language use in classes, there have little study been conducted in Ethiopian contexts. Accordingly, it seemed this current study tried to explore reasons why secondary school EFL teachers in Wolaita zone use Amharic while teaching English. The major purposes of using Amharic in this case were discussed as follows.

Questionnaire responses showed that majority of EFL teacher use Amharic for variety of purposes. Among others, the Teachers' level of fluency in target language (English) was rated as the major pushing factor for using Amharic in EFL classes. That is, most of the teachers 72 (41\%) were dominantly used Amharic because of their poor English proficiency. Though not all teachers were suffering from low English proficiency, the researcher observed most of them were not good at speaking it regardless of their level of subject matter knowledge. Besides, the students' interview result also proved as their English teachers' fluency in English is poor to use it appropriately.

Regarding EFL teachers purposes to translate English concepts in Amharic, the study revealed this method as the second most dominantly way of teaching English in the study area. In relation to this, Emily Boersma and Yinager Teklesellassie, 2017 study indicated that Teachers translate what they have already said in English into Amharic [10]. Hence, $54(30 \%)$ of respondents in current favored this idea and responded that their English teachers translate English concepts into their L2 (Amharic). Moreover, the teachers' and students' interview results also indicated it is the fact that teachers used this method.

Based on the data presented in the above table 4, it is right to assume that Amharic is comfortable means of oral communication than English language for the teachers because it is working language of Ethiopia. For this reason, most of the teachers favored Amharic than English language to conduct teaching-learning processes in classes. Out of total populations, $29(16 \%)$ respondents rated as their teachers favored speaking Amharic than English to perform classroom tasks.

Scholars support L1 use in second or foreign language classrooms for its relevance in learners' effectiveness. In the case of current study, it is assumed that the learners better understand English concepts easily if it is supported by their mother tongue (Wolaita) or L2 (Amharic) languages. Both the students' interview and questionnaire results indicated that significant numbers of students $18(10 \%)$ need teaching of English should be supported either by their L1 or L2 to facilitate what has been taught in target language.

Apart from this, it was also indicated that few teachers used Amharic to pass time than educational purposes. As the interview result indicated, such teachers were those who are taken as careless to what they do and divert the class into unnecessary jokes and talks that were out of the lessons of the day. Besides, questionnaire results showed that $5(3 \%)$ of the respondents responded some of their English language teachers waste their time talking issues out of context in Amharic. Overall results presented in the above table 4 showed that a significant amount of the classroom discourse involved abandoning the target language in favor of the students' second language (Amharic).

Table 5. Responses on Students' Perceptions of EFL Teachers Use of Amharic in Classes.

\begin{tabular}{|c|c|c|c|}
\hline & Items & Quantity (No) & Percent (\%) \\
\hline \multirow{5}{*}{$\begin{array}{l}\text { I like my English language teacher's use of Amharic while } \\
\text { teaching English lessons. }\end{array}$} & Strongly agree & 42 & 24 \\
\hline & Agree & 84 & 47 \\
\hline & Neutral & 32 & 18 \\
\hline & Disagree & 20 & 11 \\
\hline & Strongly dis agree & - & - \\
\hline
\end{tabular}


Some local studies conducted on the use of Amharic (L1) in EFL classes indicated that the students felt comfortable while their English teachers use it. In the case of current study, it was found out that $84(47 \%)$ or majority secondary school students whose mother tongue (L1) were Wolaita language and Amharic is their second language (L2) rated the use of Amharic in English classroom as important for their learning. Besides, its use was also perceived as positive by 42 (24\%) respondents whose feeling towards the situation was strongly agreed. One can understand from the above mentioned results that two-third of the respondents have positive attitude towards using Amharic in class. In the same token, Atta Galali, Emrah Cinkara, 2017 foundout that Japanese students preferred teachers who know their native language because they found L1 use to be helpful. Hence, they wanted their teachers to explain ideas and present new vocabularies in their native language [11].

On other hand, the study identified significant numbers of students32 (18\%) who responded as they were not yet decided whether using Amharic during EFL classes is important or not. During interviewing, the students did elaborate the reasons for their feeling as neither positive nor negative was regarding their language preferences. That is, they prefer the support of their native language (Wolaita) than Amharic because both Amharic as well as English is their native language for ease of Understanding target language (English). Moreover, the observation results also revealed that most of the student-student as well as teacherstudent interactions were conducted in the learners' mother tongue than Amharic. Regarding this, Hidayati, I. N. (2012) study revealed as the Students claimed that they became confused and, consequently, disinterested when English was over-used in their classes.

However, those students who opposed use of Amharic accounted $20(11 \%)$ among total populations. Though the respondents were few in numbers, the idea that the students and teachers raised during the interviewing was convincing. That is, they argued that the overuse of Amharic affects target language competence. Besides, the curriculum devised by Ethiopian Ministry of Education also favored this idea as Media of instruction for secondary school students in the country should be English language. In line with this, the respondents concluded that using either the learners' L1 or L2 in such classes is not acceptable even if they themselves as well as most of their EFL teachers have practiced it.

\subsection{Findings of the Study}

Current study employed randomly selected students and teachers as sources of data. The reliable data were collected through Questionnaire, interview, and classroom observations. These Quantitative and qualitative data were analyzed and findings of the study drawn as follow. Amharic language is second language (L2) and Wolaita language is mother tongue for target populations of the study. They learn English as foreign language starting from junior schools. Despite, significant numbers of English language teachers use Amharic while teaching English for different purposes. Accordingly, there were agreements among students regarding such uses of L2 in EFL classes. Again, it was also identified that most of EFL teachers dominantly used Amharic than target language though few of them effectively employed it. In effect, general use of Amharic in English classes was perceived by some students as good.

\section{Conclusions and Recommendations}

\subsection{Conclusions}

Based Overall findings of the study, the following conclusions were reached. English language is media of instruction for participants of the study. Despite, almost all EFL teachers dominantly used Amharic than target language. The purpose of EFL teachers' use of Amharic while teaching English language were to translate English concepts, to favor L1 use, to Support learners, and to waste time. Teachers' lacks of English fluency was also another factor for Amharic use in EFL classes. Regarding the students feeling towards their teachers' use of Amharic, they have shown positive perception. In conclusions, the students felt comfortable as their teachers use Amharic in EFL class instructions.

\subsection{Recommendations}

Based on the findings and conclusions of the study, it is recommended that EFL teachers should avoid over use the learners L2 (Amharic) in EFL classes that reduce their opportunity to practice target language. There should also be curriculum design that encourages teachers to apply target language effectively than mother tongue or second language support in EFL classes. Besides, there should also be capacity building activities and professional development done so as to enhance teachers' English proficiency.

\section{References}

[1] Mohammed Hamid Al Ta'ani, 2019. The Use of Arabic (L1) in the EFL Class rooms: How Do Umm Al Quwain Teachers and Students Perceive It? International Journal of Contemporary Education, Vol. 2, No. 2; October 2019; ISSN 2575-3177 E-ISSN 2575-3185; URL: http://ijce.redfame.com.

[2] Cook, V. (2001). Using the first language in the classroom. Canadian Modern Language Review, 57 (3), 403-423. https://doi.org/10.3138/cmlr.57.3.402.

[3] Nation, P. (2003). The role of the first language in foreign language learning. Asian EFL Journal, 5 (2), 1-18.

[4] Sampson, A. (2012). Learner code-switching versus English only. ELT Journal, 66 (3), 293-303.

[5] Skehan, P. (2001). Comprehension and production strategies in language learning. In C. N. Candlin and N. Mercer (Eds.), English language teaching in its social context (pp. 75-89). New York: Routledge. 
[6] Turan Pakera, and Özlem Karaagaç, 2015. The use and functions of mother tongue in EFL classes. Procedia - Social and Behavioral Sciences 199 (2015) 111-119.

[7] Kifle Bidika, Temesgen Mereba, and Yemanebirhan Kelemework, 2017. An Investigation of Teachers' Use of Official Language (Amharic) in English as a Foreign Language. IJERT Volume 8 June 2017.

[8] Abiy, Y. \& Mohammed, B. (2011). Frequency, purpose and application of using Amharic in teaching English in Bahir Dar general elementary schools. Ethiopian Journal of Education and Sciences, 6, 61-80.

[9] Abiy Yigzaw, 2012. Impact of L1 Use in L2 English Writing Classes. Ethiop. J. Educ. \& Sc. Vol. 8 No 1 September 2012.

[10] Emily Boersma and Yinager Teklesellassie, 2017. Prevalence and Causes of the Use of Amharic in Content subjects and students' attitudes towards Its Use. The 4th international conference on language, culture, and communication. March 17-18, 2017; Bahir Dar University, Bahir Dar, Ethiopia.

[11] Atta Galali, Emrah Cinkara, 2017. The Use of L1 in English as a Foreign Language Classes: Insights from Iraqi Tertiary Level Students. ALLS 8 (5): 54-64.

[12] Mahmoudi, L., \& Amirkhiz, S. (2011). The Use of Persian in the EFL Classroom the Case of English Teaching and Learning at Pre-University Level in Iran. English Language Teaching, 4 (1), 135-140.

[13] Hidayati, I. N. (2012). Evaluating the Role of L1 in Teaching Receptive Skills and Grammar in EFL Classes. Indonesian Journal of Applied Linguistics, 1 (2), 1732.

[14] Seyed Ali Ostovar-Namaghi, Shabnam Norouzi, 2015. First Language Use in Teaching a Foreign Language: Theoretical Perspectives and Empirical Findings. US-China Foreign Language, September 2015, Vol. 13, No. 9, 615-622 doi: 10.17265/1539-8080/2015.09.001.

[15] Ahmad Shah Qasemi Ainol Haryati Ibrahim and Mohammad Habib Jilani 2016. Perceptions of Jawzjan University Engineering Graduates towards using First Language in EFL Classes. Research Journal of Recent Sciences; Vol. 5 (9), 6264, September 2016. 